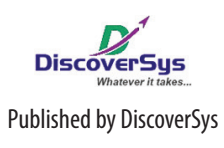

\section{Readiness to change towards accredited public health centres (PHCs) in West Lombok}

\author{
I Made Santiana, ${ }^{1}$ Ni Made Sri Nopiyani, ${ }^{2}$ \\ Dyah Pradnyaparamita Duarsa ${ }^{2}$
}

CrossMark

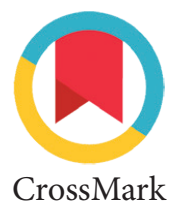

(1)


influenced by content changes, process changes, context changes, and individual attributes. ${ }^{6}$

\section{METHODS}

A cross-sectional survey was employed in West Lombok District involving seven non-accredited PHCs. Data was collected from February to March 2017. As many as 165 out of 310 PHC's staff (functional and structural) were recruited by systematic random sampling.

Data collected were socio-demographic characteristics, duration of service, content changes (administrative systems, working procedure, and technology improvement), process changes (promotional strategy and staff engagement), context changes (managerial support from district health office), individual attribute (organisational commitment) and the readiness to change towards accredited PHC. Selfadministered questionnaire was used and it took about 30 minutes to complete the questionnaire. Data was analysed using STATA SE 12.1, and logistic regression was employed to examine the association between readiness to change and independent variables. All independent variables with a $p$ value $<0.25$ in the bivariate analysis were included in the multivariate analysis. Ethical clearance has been obtained from the Human Research Ethics Committee Faculty of Medicine Mataram University.

\section{RESULTS}

Table 1 presents the respondents characteristics which include age, gender, education, working unit, type of employment, and duration of service. The highest proportion of the respondents aged $\geq 30$ years $(61.2 \%)$, female $(79.4 \%)$, diploma graduates $(60.0 \%)$, nurse $(31.5 \%)$, working in the community health programs section (53.9\%), and having $\geq 7$ years of service (54.5\%).

Table 2 shows the proportion of staff readiness to change towards accredited PHC based on four dimensions of organisational change model. As many as $72.1 \%$ of respondents were ready for the accreditation. Almost all respondents (97.0\%) considered these changes as appropriate-indicating that the majority of respondents perceived the decision on accreditation is in the best interest of the whole organisation. In the context of the change efficacy dimension, only $46.1 \%$ respondents perceived that they could achieve the accreditation target. The majority of respondents $(89.7 \%)$ reported that they received support from the district health office to achieve the accreditation. Additionally, as many as $82.4 \%$ of respondents perceived that they might gain personal benefits from the accreditation.

Table 3 presents the association between readiness to change and content changes (administrative system, working procedure, and technology improvement), process changes (promotional strategy and staff engagement), context changes (support from health offices), and individual attribute (organisational commitment). It can be observed that there are siginficant associations between readiness to change with good perceptions on content changes, process changes, context changes and individual attribute.

Table 4 shows the results of multi variate analysis between the readiness to change with administrative systems, working procedure, staff engagement, organisational commitment, promotional strategy, technology, support from health offices, age, and years of service. It was found that readiness to change is associated with administrative systems $(\mathrm{AOR}=4.47$; 95\%CI: 2.05-9.74) and working procedure $(\mathrm{AOR}=2.95 ; 95 \% \mathrm{CI}: 1.19-7.30)$. However, there was no significant association between readiness to change with technology improvement, promotional strategy, staff engagement, support from health offices, organisational commitment, age, and duration of service.

\section{DISCUSSION}

Our study reveals that the majority of PHC's staff are ready for the accreditation. However, most staff perceive that they are lacking in capacity to achieve the accreditation. They receive sufficient support from the district health office. They also believe that the PHC will gain multiple benefits from the accreditation. The bivariate analysis shows that there is a positive association between readiness to change with administrative systems, working procedure, technology improvement, promotional strategy, staff engagement, support from health offices, and organisational commitment. However, the multivariate analysis shows a significant association between readiness to change only with administrative systems and working procedure. This could be due to an inter-dependence across variables of content changes, process changes, context changes, and individual attribute. Administrative systems cover the perception of staff regarding activities to support accreditation policy which include documentation of planning, implementation, and monitoring-evaluation. An efficient administrative system might provide clear direction for all staff to achieve the accreditation. Our study confirms that those who perceive to have efficient administrative systems are more confident in achieving the accreditation. This is due to the fact that the majority of 
Table 1 Characteristics of respondents based on age, gender, education, employment, working section, and duration of service

\begin{tabular}{|c|c|c|}
\hline Characteristic & $\mathbf{n}$ & $\%$ \\
\hline Age $(\operatorname{mean} \pm S D, \min -\max )$ & $34.3 \pm 8.2$ & $21-55$ \\
\hline$<30$ years & 64 & 38.8 \\
\hline$\geq 30$ years & 101 & 61.2 \\
\hline \multicolumn{3}{|l|}{ Gender } \\
\hline Male & 34 & 20.6 \\
\hline Female & 131 & 79.4 \\
\hline \multicolumn{3}{|l|}{ Education } \\
\hline Senior high/equivalent & 18 & 10.9 \\
\hline First grade diploma & 3 & 1.8 \\
\hline Third grade diploma & 99 & 60.0 \\
\hline Fourth grade diploma & 2 & 1.2 \\
\hline University graduate (bachelor) & 29 & 17.6 \\
\hline University graduate (vocational studies) & 14 & 8.5 \\
\hline \multicolumn{3}{|l|}{ Types of profession } \\
\hline Medical doctor & 11 & 6.7 \\
\hline Dentist & 3 & 1.8 \\
\hline Nurse & 52 & 31.5 \\
\hline Dental nurse & 5 & 3.0 \\
\hline Midwife & 44 & 26.7 \\
\hline Health analyst & 6 & 3.6 \\
\hline Pharmacist/pharmacist assistant & 4 & 2.4 \\
\hline Sanitation officer & 9 & 5.5 \\
\hline Dietician & 16 & 9.7 \\
\hline Admin staff & 13 & 7.9 \\
\hline Other health officer & 2 & 1.2 \\
\hline \multicolumn{3}{|l|}{ Working section } \\
\hline Administrative & 15 & 9.1 \\
\hline Community health program & 89 & 53.9 \\
\hline Personal health program & 61 & 37.0 \\
\hline Duration of service (mean $\pm S D$, min-max) & $9.5 \pm 8.1$ & $1-30$ \\
\hline$<7$ years & 75 & 45.5 \\
\hline$\geq 7$ years & 90 & 54.5 \\
\hline
\end{tabular}

accreditation evaluation are based on document or administrative evaluation. They are more confident for the accreditation because they already have a good documentation of planning, implementation, and monitoring/evaluation of all related programs. This finding is consistent with the concept from Holt (2007) who states that an efficient administrative system has a positive contribution to the readiness to change. ${ }^{6}$ Our finding is also consistent with a study in Magelang City which found a positive association between readiness to change and administrative systems.
The present study found an association between working procedure and PHC's staff readiness for the accreditation. Working procedure includes the availability of the standard operational procedures (SOP) and its implementation. Our study revealed that respondents with good perception on working procedure are more ready for the accreditation than those with poor perception. They believe that availability and compliance towards SOP are keys for achieving accreditation. Our respondents perceive that every activity should have SOP to provide direction during the implementation. PHC staff members perceived that they have followed the SOP for the human resource management and administration, community health programs management, and documentation for quality improvement activities. Our study is consistent with Holt (2007) who argues the positive association between working procedure and readiness to change among staff members. ${ }^{6}$

This study found no significant association between working engagement with PHC's staff readiness for the accreditation. Although many PHC's staff have been trained on the PHC accreditation processes, the fact that only small number of them were actually involved in the decision making could explain this insignificant association. Our finding is not consistent with other studies in Surabaya and Medan which found a direct effect of staff engagement and organisational changes. ${ }^{8,9}$

It also found that there is no significant association between technology improvement with PHC's staff readiness for the accreditation. This might be related to the small proportion of PHCs that use computer to support their health programs. This finding is inconsistent with Holt who suggests a positive association between technology and readiness to change. ${ }^{6}$

The present study found no significant association between promotional activities and PHC's staff readiness for the accreditation. This may be contributed by the majority of PHCs in our study utilise verbal instead of written announcement regarding the accreditation. Desplaces suggests that better promotional strategies can lead to successful organisational changes. ${ }^{10}$

Furthermore, this study also found no significant association between context changes (support from health offices) with PHC's staff readiness for the accreditation. The health offices provide technical and non-technical assistance to PHCs during the preparation for accreditation. However, the health offices do not provide ongoing provisions on improving the quality of healthcare facilities. Additionally, the health offices also fail to provide greater opportunity for PHC staff member to attend training on accreditation processes. Our finding is 
Table 2 Readiness to change and its dimensions among PHC's staff

\begin{tabular}{lcc}
\hline Variable & $\mathbf{n}$ & $\%$ \\
\hline Readiness to change & 119 & 72.1 \\
Yes & 46 & 27.9 \\
No & & \\
Appropriateness & 160 & 97.0 \\
Appropriate & 5 & 3.0 \\
Not appropriate & & \\
Management support & 148 & 89.7 \\
Adequate & 17 & 10.3 \\
Not adequate & & \\
Change efficacy & 76 & 46.1 \\
Capable & 89 & 53.9 \\
Not capable & & \\
Personal valence & 136 & 82.4 \\
Good perception & 29 & 17.6 \\
Poor perception & 165 & 100.0 \\
Total & &
\end{tabular}

inconsistent with a study in Surabaya City suggesting a positive association between readiness to changes and the availability of managerial support from health offices. ${ }^{7}$

This study suggests no significant association between individual attribute (organisational commitment) and readiness to change among PHC staff member. It could be argued that the lack of ownership could explain this finding. PHC's staff refuses to spend extra hours to complete the administrative requirements for the accreditation processes. Organisational commitment is a key determinant of staff loyalty and dedication to achieve the organisational goals. This finding is consistent with a study in Jakarta. ${ }^{11}$ However, another study in the same city suggests a strong association between organisational commitment and readiness to change among staff member. ${ }^{12}$ Similarly, a study in Bali Province argues a positive association between working commitment and quality of service at the PHC. ${ }^{13}$

Table 3 Association between readiness to change with content changes, process changes, context changes, and individual attribute

\begin{tabular}{|c|c|c|c|}
\hline \multirow[b]{2}{*}{ Variable } & \multicolumn{2}{|c|}{ Readiness to change } & \multirow[b]{2}{*}{ p value } \\
\hline & $\begin{array}{l}\text { Ready } \\
\text { n (\%) }\end{array}$ & $\begin{array}{c}\text { Not ready } \\
\text { n (\%) }\end{array}$ & \\
\hline \multicolumn{4}{|c|}{ Content changes } \\
\hline \multicolumn{4}{|c|}{ Administrative systems } \\
\hline Good & $85(85.9)$ & $14(14.1)$ & $<0.001$ \\
\hline Poor & $34(51.5)$ & $32(48.5)$ & \\
\hline \multicolumn{4}{|c|}{ Working procedure } \\
\hline Good & $105(78.9)$ & $28(21.1)$ & $<0.001$ \\
\hline Poor & $14(43.8)$ & $18(56.2)$ & \\
\hline \multicolumn{4}{|c|}{ Technology } \\
\hline Good & $110(75.3)$ & $36(24.7)$ & 0.011 \\
\hline Poor & $9(47.4)$ & $10(52.6)$ & \\
\hline \multicolumn{4}{|c|}{ Process changes } \\
\hline \multicolumn{4}{|c|}{ Promotional } \\
\hline Good & $117(74.5)$ & $40(25.5)$ & 0.002 \\
\hline Poor & $2(25.0)$ & $6(75.0)$ & \\
\hline \multicolumn{4}{|c|}{ Staff engagement } \\
\hline Good & $79(82.3)$ & $17(17.7)$ & 0.001 \\
\hline Poor & $40(58.0)$ & $29(42.0)$ & \\
\hline \multicolumn{4}{|c|}{ Context changes (support from health office) } \\
\hline Good & $104(77.6)$ & $30(22.4)$ & 0.001 \\
\hline Poor & $15(48.4)$ & $16(51.6)$ & \\
\hline \multicolumn{4}{|c|}{ Individual attribute (organisational commitment) } \\
\hline Good & $96(79.3)$ & $25(20.7)$ & 0.001 \\
\hline Poor & $23(52.3)$ & $21(47.7)$ & \\
\hline
\end{tabular}


Table 4 Adjusted OR of content changes, process changes, context changes, and individual attribute

\begin{tabular}{|c|c|c|c|}
\hline Variable & Adjusted OR & $95 \% \mathrm{Cl}$ & p value \\
\hline \multicolumn{4}{|l|}{ Age } \\
\hline$\geq 30$ years & 1 (Ref) & & \\
\hline$<30$ years & 0.59 & $0.27-1.32$ & 0.205 \\
\hline \multicolumn{4}{|c|}{ Duration of service } \\
\hline$<7$ years & 1 (Ref) & & \\
\hline$\geq 7$ years & 0.36 & $0.08-1.52$ & 0.166 \\
\hline \multicolumn{4}{|c|}{ Administrative systems } \\
\hline Poor & 1 (Ref) & & \\
\hline Good & 4.47 & $2.05-9.74$ & $<0.001$ \\
\hline \multicolumn{4}{|c|}{ Working procedure } \\
\hline Poor & 1 (Ref) & & \\
\hline Good & 2.95 & $1.19-7.30$ & 0.019 \\
\hline \multicolumn{4}{|c|}{ Staff engagement } \\
\hline Poor & 1 (Ref) & & \\
\hline Good & 2.04 & $0.92-4.52$ & 0.079 \\
\hline \multicolumn{4}{|c|}{ Organisational commitment } \\
\hline Poor & 1 (Ref) & & \\
\hline Good & 1.75 & $0.72-4.27$ & 0.216 \\
\hline \multicolumn{4}{|c|}{ Promotional activities } \\
\hline Poor & 1 (Ref) & & \\
\hline Good & 2.09 & $0.26-16.35$ & 0.479 \\
\hline \multicolumn{4}{|c|}{ Support from the health offices } \\
\hline Poor & 1 (Ref) & & \\
\hline Good & 1.32 & $0.45-3.83$ & 0.602 \\
\hline \multicolumn{4}{|c|}{ Technology improvement } \\
\hline Poor & 1 (Ref) & & \\
\hline Good & 1.43 & $0.42-4.79$ & 0.557 \\
\hline
\end{tabular}

Based on the above findings, improving staff readiness for PHC accreditation requires ongoing efforts to include all staff member on the accreditation planning processes, implementing information technology in every administrative activity, providing written information regarding the accreditation procedures, increasing the support from district health office, and improving the organisation commitment to direct staff ownership and quality improvement through the accreditation.

\section{CONCLUSION}

The majority of PHC's staff support the idea of organisational change. Administrative systems and working procedures influence the staff perception of organisational changes. However, there is no significant association between staff perception on organisational change with technology improvement, promotional activities, staff engagement, managerial support from district health office, and organisational commitment.

\section{ACKNOWLEDGEMENT}

We would like to thank all respondents, the Head of West Lombok District Health Office, and all stakeholder for supporting this study.

\section{REFERENCES}

1. Ministry of Health of Indonesia. Peraturan Menteri Kesehatan Republik Indonesia Nomor 46 Tahun 2015 tentang Akreditasi Puskesmas, Klinik Pratama, Tempat Praktik Mandiri Dokter, dan Prakter Mandiri Dokter Gigi [The Ministry of Health Regulation No. 462015 on Accreditation for Public Health Centre, Private General Practitioner, and Private Dentist]. Jakarta: Ministry of Health of Indonesia; 2015. 
2. Ministry of Health of Indonesia. Permenkes 71 tentang Pelayanan Kesehatan pada Jaminan Pelayanan Kesehatan Tahun 2013 [The Ministry of Health Regulation No. 71 on Delivery of Health Services within the National Health Security 2013]. Jakarta: Ministry of Health of Indonesia; 2013.

3. Ministry of Health of Indonesia. Laporan Akuntabilitas Kinerja Instansi Pemerintah Tahun 2016 [Performance Accountability of Government Institutions Report 2016]. Jakarta: Direktorat Jenderal Pelayanan Kesehatan (Directorate General of Health Services); 2016.

4. West Lombok District Health Office. Laporan Akreditasi Puskesmas Tahun 2016 [Accreditation Report of Public Health Centre in 2016]. Gerung: UPTD Data Informasi; 2016. Available at: https://dikeslobar.wordpress.com.

5. West Nusa Tenggara Provincial Health Office. Rencana Strategis Dikes Propinsi NTB Tahun 2014-2019 [Strategic Plan of West Nusa Tenggara Health Office 2014 - 2019]. Mataram: West Nusa Tenggara Provincial Health Office; 2014.

6. Holt DT, Armenakis AA, Feild HS, et al. Readiness for organizational change: the systematic development of a scale. The Journal of Applied Behavioral Science. 2007; 43(2): 232-255.

7. Nirmala. Upaya peningkatan readiness for change dalam rangka akreditasi puskesmas (Study kasus di Kabupaten Magelang) [Improving readiness for change towards health centre accreditation-a case study in Magelang District]. (Thesis) Surabaya: Universitas Airlangga; 2016.

8. Pramadani $A B$, Fajrianthi. Hubungan antara komitmen organisasi dengan kesiapan untuk berubah pada karyawan Divisi Enterprise Service (DES) Telkom Ketintang Surabaya [Association between organisational commitment and readiness to change among staff of entreprise service division of Telkom Ketintang Surabaya]. Jurnal Psikologi Industri dan Organisasi. 2012; 1(2): 102-109.
9. Zulkarnain, Hadiyani S. Peranan komitmen organisasi dan employee engagement terhadap kesiapan karyawan untuk berubah [The role of organisational commitment, employee engagement, towards organisational change]. Jurnal Psikologi. 2014; 41(1): 19-35.

10. Desplaces D. A multilevel approach to individual readiness to change. Journal of Behavioral and Applied Management: 2005; 7(1): 25-39.

11. Periantalo J, Mansoer WD. Faktor-faktor yang mempengaruhi kesiapan untuk berubah pegawai Dirjen $\mathrm{PQR}$ [Factors associated to readiness to change among staff of PQR Directorate General]. Jurnal Psikologi Sosial. 2008; 14(3): 195-203.

12. Mangundjaya WLH. Are organizational commitment and employee engagement important in achieving individual readiness for change?. Humanitas. 2012; 9(2): 1-8.

13. Artini, Suarjana IW, Wijaya IPG. Hubungan penerapan manajemen puskesmas dan komitmen kerja dengan mutu pelayanan pengobatan di Puskesmas Karangasem [Association between implementation of health centre management, working commitment and treatment quality at Karangasem Public Health Centre]. Public Health and Preventive Medicine Archive. 2016; 4(1): 43-51.

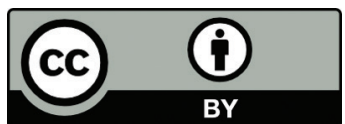

This work is licensed under a Creative Commons Attribution 